\title{
THE ANTHROPOLOGIST AS CITIZEN
}

\author{
Joan Metge
}

\begin{abstract}
In the ASAANZ's Principles of Professional Responsibility 'responsibility to the wider society' comes second, immediately after 'responsibility to research participants'. Anthropologists have a range of responsibilities to the wider society, including, but not restricted to, the responsibility of social criticism. Drawing on my own experience, I explore the varied history, difficulties and dilemmas of our attempts to carry out our responsibilities as citizens.
\end{abstract}

Illustrating the theme of ASAANZ 2005 (Beyond Ethnography), Jim Urry's cartoon depicts a palisaded village named Ethnographyville, a road disappearing into low hills and a refracted glow in the sky beyond signal the presence of Anthropologyland. Urry spelled out the critique implicit in his cartoon in his conference paper, a revised version of which is published in this issue. In this paper, he argues that Anglo-American anthropologists have been unduly constrained by their preoccupation with ethnography and sets out an alternative, French-derived model which relates ethnography, ethnology and anthropology as successive and increasingly wide ranging stages in an overarching discipline devoted to the study of all humankind.

While Urry's analysis is historically grounded and thought-provoking, it is focused exclusively on the discipline's internal relationships and issues. But anthropology and anthropologists do not exist in a vacuum: with the rest of academia they are an integral part of wider national and international societies.

ENGAGEMENT IN A CHANGING CONTEXT

In New Zealand anthropologists began grappling with practical problems even before the subject was firmly established in the universities. ${ }^{1}$ Over the years since, their engagement has changed in degree and direction with changing 
attitudes, policies and events in the wider New Zealand society.

When Ralph Piddington took up his appointment as Professor of Anthropology at the University of Auckland in 1950, assimilation was official government policy; the senior officials in the Department of Maori Affairs were all Pakeha; Maori culture was popularly believed to be dying; more than 25 laws discriminated against Maori allegedly 'for their own protection'; and Maori migration to the cities was denigrated as a 'drift' involving moral decline. Criticism of the state of national or local race relations was dismissed as troublemaking. In many universities round the world applied anthropology was looked down on, marginalised or excluded.

Piddington challenged current views in New Zealand by insisting on the relevance of anthropology to the community at large. Before arrival he had written papers designed to inform, advise and change attitudes among missionaries and colonial administrators (Piddington and Graham 1940, Piddington 1951). In 1952, he presented a paper to the New Zealand Government suggesting that the Anthropology Department in Auckland be expanded to train administrators and other personnel and to conduct research into the practical problems of welfare and development among Maori and in New Zealand's Island Territories. The government officials addressed boggled at the cost and negotiations broke down (Metge 2000).

Undeterred Piddington made a round of visits to Maori communities, gave numerous talks to community groups, convened a Maori Research conference at the University of Auckland in 1953 and developed his thinking on intergroup (especially Maori/Pakeha) relations in papers presented at interdisciplinary conferences open to the public: the 7th Pacific Congress 1951, ANZAAS 1957, and the 9th Pacific Congress 1960 (Piddington 1951, 1960). Entitled 'Action Anthropology', the latter drew on the work of Sol Tax. In the conservative climate of the time, his papers and talks were controversial, resisted by many as an attack on the status quo, welcomed by others as a breath of fresh air. Maori responded to Piddington with enthusiasm, for he affirmed their own vision and aspirations. Piddington developed his key ideas of 'symbiosis', 'emergent development' and 'action anthropology' in his teaching, but did not publish them in a generally accessible form until 1968 (Piddington 1968).

At a time when the University of New Zealand required students to go overseas for doctoral study, Piddington fought for the right of his students to do fieldwork in New Zealand. Among those he supported were Eric Grimes (Indians in New Zealand) and myself (Maori in urban and rural areas: Metge 1964), 
Geoff Chapple (the forest communities of the Volcanic Plateau), Pat Hohepa (his home community of Waima: Hohepa 1964) and Bernie Kernot (Maori leadership in Pukekohe: Kernot 1972). He established warm relations with the local and regional Councils of Adult Education, encouraging Anthropology staff and students to lecture for them part-time.

Newly graduated with an MA in Geography, I enrolled in Piddington's Stage 2 course in Anthropology in 1952. Having lived in racially divided communities as a child, I found Piddington's emphasis on community outreach highly congenial. Doing fieldwork under his supervision from 1953 to 1955 before going overseas for doctoral study, I established what was to be a lifelong pattern of alternating fieldwork in Maori communities with sharing my developing understanding of Maori life and worldview with members of the wider society, including church groups and government officials, in talks, seminars and workshops.

Meanwhile, John Booth, a forgotten pioneer with an MA from the University of New Zealand and a Diploma in Anthropology from London University, found a niche in New Zealand's Public Service as its first anthropologist. Employed as a social researcher in the Department of Maori Affairs throughout the 1950 s and 196os, he played a major role in compiling the information which underpinned the Hunn Report of 1960 and contributed to the development of the policy of integration (Booth 1959, Hunn 1961, Hunn and Booth 1962). A recent emigrant from Europe and widely read in Continental anthropology, Eric Schwimmer worked for the Department of Maori Affairs in Wellington as editor of the magazine Te Ao Hou in the 1950s and for the Department of Education as a teacher in Northland before seeking advanced training overseas. Two books published after his departure helped educate the wider society on Maori matters (Schwimmer 1966, 1968). ${ }^{2}$

When I returned to Auckland in 1958 after completing my doctorate at the London School of Economics, Piddington was fully occupied managing a growing Anthropology Department but he continued to encourage staff and students to engage in community outreach. From 1959 to 1965 I worked with lecturers from Anthropology and other Auckland University departments as rapporteurs for the Young Maori Leaders' Conferences organised by the Department of University Extension.

As Tutor Organiser with University Extension in Auckland from 1961 to 1964 and as founding member of the Anthropology Department at Victoria University of Wellington from 1965 to 1988, I worked with Maori partners raising 
funds for the Maori Education Foundation, organising marae visits for mixed groups of Maori and Pakeha, hosting marae groups on reciprocal visits to the city, and participating in in-service training for public servants. ${ }^{3}$ In the $1960 \mathrm{os}$ and early 1970 s the emphasis was on producing soundly based ethnographic evidence and logical arguments with the aim of effecting changes in Pakeha attitudes towards Maori, particularly among the Pakeha in positions of power in the Departments of Maori Affairs, Education, Social Welfare and Health, in hopes of indirectly effecting improvements in policy. ${ }^{4}$

By 1970, there had been advances to which I like to think I had made some contribution: all the discriminatory laws had been repealed; the 'Maori urban drift' was recognised as a purposeful migration; participants in the Young Maori Leaders' Conferences were moving into positions of power; and Maori tertiary students had increased significantly in number and level of attainment. But the level of awareness of things Maori remained frustratingly low in the general population and in many government quarters.

In the 1970s young Maori activists from inside and outside the universities began to make their presence felt, their concerns crystallised by a Maori Youth Conference organised in 1973 by Ranginui Walker, an anthropology graduate working in Continuing Education at the University of Auckland. During the 1970s, Wiremu Parker, Koro Kapunga Dewes, Bernie Kernot and myself at Victoria University of Wellington provided background support (including submissions to relevant government bodies and chauffeuring duties) for the Maori language campaigns conducted by student bodies, Nga Tama Toa and Te Reo Maori Society. We adopted a policy of referring seekers after opinions on Maori issues to suitably qualified Maori spokespersons, keeping a file of names for the purpose. Staff and students in Anthropology Departments at Auckland, Otago and Massey universities worked along similar lines. From his base in Continuing Education, Ranginui Walker set about educating the general public about Maori history, tikanga and aspirations through columns in the New Zealand Listener and Metro magazine (Walker 1987). During this decade the drive for tino rangatiratanga (self-governance) by Maori staff and students led to Maori Studies being separated from Anthropology and established as a department in its own right at Auckland and Wellington universities. The extent of Maori content in Anthropology courses and the proportion of Maori students enrolling in Anthropology both decreased significantly as a result.

In the early 1980 s, some proponents of tino rangatiratanga pursued an unofficial campaign to exclude non-Maori from research on Maori topics, claiming 
that only Maori researchers could fully understand tikanga Maori, Maori sufferings and aspirations. At the time I was engaged in research on the whanau and Maori methods of teaching and learning in Auckland and the Far North. ${ }^{5}$ Like other Pakeha researchers, ${ }^{6}$ I sustained a highly personalised attack on my work and integrity by one champion of this view, who ordered me to cease work forthwith. Seeking out the Maori groups I was currently working with, I received such reassuring support and affirmation that I was able to complete my fieldwork and eventually publish the results. ${ }^{7}$ Some Pakeha anthropologists who had built warm relations with particular Maori groups over many years also survived this very difficult period, ${ }^{8}$ but most anthropologists in the making turned their attention in other directions.

Through the late 1980 os and 1990s ideologically driven restructuring within and beyond the university gave preferential treatment to research conducted in New Zealand and identified as socially relevant. Taken together with unwelcoming Maori attitudes, these changes have produced a flowering of anthropological research among Pakeha, Pacific Islanders and other minority groups, especially in the areas of health and education, and much of it directly relevant to social planning and policy. Some of this research has been organised and carried out by teams under the supervision of university staff: for example, Julie Park and Judith Simon at the University of Auckland; Sally Keeling in the Medical School in Christchurch; and Ruth Fitzgerald at the University of Otago. With restrictions on the growth of Anthropology Departments, Anthropology graduates have increasingly found employment outside academia in government departments, local bodies, businesses and as self-employed researchers and consultants. Kathryn Scott, a contributor to this volume, is a recent adventurer in this field.

Over the last ten to fifteen years, Maori opposition to Pakeha researchers with anthropological training has declined and a number have been recruited to work on Waitangi Tribunal claims, often on behalf of the claimants. Their work is, however, constrained by the requirements of the claims process - it offers little scope for theoretical development, the results have to be approved by the commissioning claimant and they are restricted in availability and circulation. Ironically, as anthropological interest in Maori affairs and Maori-Pakeha relations has declined, there has been a marked increase in the number of historians working in those areas, both Maori and Pakeha. ${ }^{9}$

For myself, retirement from Victoria University of Wellington in 1988 meant freedom to visit my fieldwork area whenever and for as long as I chose and to pick up challenges as they arose. Over the last seventeen years I have written sixteen 
reports, three affidavits and thirteen submissions on matters of law and social policy, some in response to requests from government departments, lawyers and the Law Commission, others on my own initiative; I have spoken to a wide range of community groups, run workshops with Maori partners, ${ }^{10}$ and developed my ideas on the Treaty of Waitangi and its contemporary relevance. Drawn into dialogue and working relations with members of other disciplines, I was gratified to find how responsive they were to anthropological ideas and practice.

Attending Waitangi Tribunal hearings on the Muriwhenua land claims in the early 1990s, I was stimulated to undertake new research into Maori fishing practice and cross-cultural encounters in Muriwhenua (the Far North) in the 1830s and ended up writing three lengthy submissions to the Tribunal (Metge 1991, 1992, 1993). In the second and third of these I drew on insights gained in research in the contemporary scene, particularly on the problems of cross cultural communication (Metge and Kinloch 1978) to make sense of events in the decade before the Treaty of Waitangi was signed. Applying anthropological principles and findings to the study of the past was an exciting change in orientation for me, a change which proved illuminating and was taken seriously by the Tribunal members sitting on the Muriwhenua case (Waitangi Tribunal 1997, p. 74).

Freedom to engage with the wider society so directly, however, came at a price, in particular, constant interruptions to my planned writing schedule and loneliness working from a home base outside academia, without daily contact with anthropological colleagues. I gave up trying to keep abreast of theoretical developments in the discipline.

Other anthropologists have also found retirement both liberating and distancing. Bernie Kernot, for example, is exploring issues of human rights and spirituality, and Robin Fleming has started a third career as a creative writer. Unfortunately, both have allowed their membership of ASAANZ to lapse.

In the years since I retired the universities have undergone extensive changes in structure and funding. No longer personally involved, I leave others to explore what this means for anthropologists engaged in community outreach. I worry that the escalating demands of university employment and the need to produce peer reviewed publications constrains university anthropologists from the sort of community involvement I have enjoyed over the years.

PATTERNS OF ENGAGEMENT

Much of the work that anthropologists do in the course of engagement with 
the wider society, whether from bases within or outside academia, is neither well known nor appreciated, either by other anthropologists or by the general public. There are good reasons for this, including issues of privacy and confidentiality, the need to focus on particular audiences, the multiplicity of reporting channels and difficulties finding publication outlets. However, lack of such knowledge handicaps university teachers in preparing students for post-graduate employment, while applied anthropologists feel cut off from professional validation and support.

To illustrate the great variety of anthropological engagement in New Zealand society, I shall briefly outline the contributions of four anthropologists with different career trajectories and interests. ${ }^{11}$

Robin Fleming, who re-trained as an anthropologist in the 1970s, worked thereafter entirely in the public sector. Research contracts with the New Zealand Children's Health Foundation and Department of Health (1979-86) were followed by successive terms as Senior Research Officer in the Department of Internal Affairs (including a secondment as Research Co-ordinator with the Royal Commission on Social Policy), Assistant Manager Health Promotion in the Health Department, Senior Policy Analyst in the Ministry of Women's Affairs, and Manager and Lead Researcher for the Intra-Family Income Study (1991-93) and the Families of Re-marriage Project (1996-98), both funded by FORST and managed from her home as base.

Bernie Kernot, working from a base in Anthropology and Maori Studies at Victoria University of Wellington from 1967 to 1997, served as a member of the Maori Buildings Committee of the Historic Places Trust (1972-76), as an honorary lecturer at Te Wananga o Raukawa, and from the late 1970s to the early 1990s, as member and Chairperson (1992-93) of the Archdiocesan Commission for Justice, Peace and Development of the Roman Catholic Church and its various councils and committees. Working in conjunction with Commission CEO, Manuka Henare, he presented eight major submissions to Parliamentary Select Committees, one to the Royal Commission on Social Policy and another to the Human Rights Commission. Since retiring from the university in 1996, he has run courses at the Wellington Catholic Education Centre, given lectures in the Defence Force Chaplains' leadership courses, convened an ecumenical seminar discussing Christian perspectives on Human Rights, and participated in an ecumenical think-tank, the Tamihana Foundation.

Working from a base in the Anthropology Department at the University of Auckland since 1981, Julie Park has been responsible for organising and leading a 
succession of team research projects in the health field, funded mainly by the Health Research Council, ALAC, the former SSRFC, FORST and the University of Auckland Research Committee. These projects have all resulted in communityoriented publications, variously dealing with: coping and social support in a new suburb (Park 1982); the place of alcohol in the lives of New Zealand women (Park ed. 1991); living with haemophilia (Park, Scott et al. 1995); the ethnographic component of a rural sustainability study (Scott, Park et al. 1997); cross-cultural infant care practices (Abel et al. 1999); roles and responsibilities in reproduction of Samoan people in Auckland (Anae et al. 2000); and the political ecology of tuberculosis (Park, Littleton et al. in press). She has also contributed to other research projects, published extensively in professional as well as academic journals, given numerous talks to community groups, supplied research based information to specialist groups like the New Zealand Haemophilia Foundation and made submissions to relevant bodies.

After twenty years working as a radiation therapist, medical researcher, freelance radio producer and journalist, Ruth Fitzgerald completed a doctorate in Anthropology in 1999 and held several polytech and university positions until confirmed as senior lecturer in the Anthropology Department at Otago University in 2006. From this university base she has worked with senior medical researchers in projects in the anthropology of health and medicine with a specific focus on ideologies of health (for example, the nature of care, contemporary health care restructuring) and biotechnologies of health and food with a specific focus on cultural significance (for example, food scares, media interpretations and public perceptions of such technologies), all with special reference to Aotearoa New Zealand.

As these examples indicate, anthropologists vary widely in personality, interests, experiences and communication skills. In carrying out our responsibiulities to the wider society we are well advised to recognise our own particular interests, capabilities and goals and to choose our audiences and the best ways of communicating with them in the light of that knowledge.

\section{COMMUNICATING WITH MULTIPLE AUDIENCES}

In a recent edition of Sites (N.S. Vol.2 No.1 2005), Chris Tremewan castigated New Zealand social scientists for failing publicly to critique the annexing of power by 'a new Maori elite'. However, it cannot be assumed that anthropologists have not spoken out on this or other issues because they have not been reported as doing so in the public media. They may have preferred to use other, less public channels of communication as likely to be more effective in 
bringing about change. For the wider society provides not one but a diversity of audiences and a range of ways of addressing them. Each has its advantages and difficulties.

At first sight, public media such as newspapers, magazines, radio, television and the internet offer the obvious way of reaching a wide, general public, but in reality this public comprises many audiences with varied tastes, attention spans and degrees of discernment. Only a minority of the members of these audiences is willing to engage with items of any depth. Access to public media outlets is guarded by gatekeepers who typically require presentations to be succinct, punchy and polemical; what they let through is often short on evidence and qualifying statements, and long on generalisation. Tightly argued statements are vulnerable to editorial cutting and misleading headlining. After some unfortunate experiences in the 1960 os (involving missing negatives, misleading headlines, and my own inability to relax on radio), I withdrew from the fray, although I have occasionally been tempted to try again, with variable success. In 2004, an article I offered to a major newspaper was refused because it was not controversial. My Waitangi Rua Rau Tau Lecture, delivered in the Beehive several days after Don Brash's speech at Orewa in 2004, was ignored by all the media except Radio New Zealand, which was involved as a sponsor of the lecture series (Metge 2004).

Communicating effectively through the public media takes self-confidence and special talents. Of the few New Zealand anthropologists who have had some success in this field, Ranginui Walker was a regular columnist in the New Zealand Listener and Metro magazine for many years, Jim Urry has risen to the occasion when asked to comment on radio at short notice and Elizabeth Rata's articles have appeared on the NZ Herald's feature page (Rata 2005). Those of us who are not gifted in this way should do more to identify those who are and encourage them to develop their skills in this area.

Personally, I have found that talks, formal and informal, to relatively small, interested audiences, and participation in focus groups and workshops are more effective ways of reaching people, ways for which I am better fitted than for work in the public eye. I have also found that their effectiveness is enhanced when I work in double harness with partners from different backgrounds from mine, mostly Maori and Pacific Islanders. Working with small groups makes it possible to engage fully with participants' minds and experience, allowing for thoughtful exploration of evidence and explanatory theories. In such settings knowledge rarely flows only one way: the speaker willing to listen to others gains new perspectives on the subject under discussion, new insights and new 
questions to answer. Encounters of these kinds typically leave no documentary record, so that it is difficult to measure their long term effect. However, I continually meet people in a variety of settings who report that the way they perceive and act in the world was radically changed by encountering anthropological ideas in such settings.

As important in a different way are reports, submissions and affidavits made to politicians, officials, lawyers, and voluntary groups, whether as a result of a request or contract or on the anthropologist's own initiative. These give writers scope to pursue arguments, provide grounding evidence and make recommendations, while remaining in control. Once presented, they become matters of public record and even if they are shelved without action by the recipients, they can be retrieved through the Public Information Act or on the internet and used as a focus for debate. I have been surprised at how often submissions I made years ago, for example on the Runanga Iwi Bill (1989), turn up in citations. The downside is that commissioned reports and submissions are largely invisible to and hence unappreciated by other anthropologists, let alone the wider public. Informants' identity has to be protected. Typically tight deadlines leave no time to seek comment or support from others. This was the case with most of the reports and submissions I have written over the last twenty years. On the rare occasions when I had time to seek the advice of colleagues, the gains were substantial.

On the face of it, the most effective way of reaching a really wide audience outside anthropology is through formally published books and articles, because they give their authors room to present in full the evidence and thinking on which their conclusions and recommendations are based, and because they are both accessible and portable to those interested in their subject matter. However, reaching beyond disciplinary limits by this means is fraught with difficulties and dilemmas.

The first problem is that of style. In order to reach non-anthropology and nonuniversity audiences it is absolutely necessary to reduce technical vocabulary to the minimum, to explain anthropological concepts and theories in plain language, and to take special steps to attract and sustain reader interest, all while maintaining scholarly integrity. This is a challenging task. Some anthropologists produce separate works for specialists and for the general public. Robin Fleming's The Common Purse, for instance, is an immensely readable synthesis of the three reports of the Intra Family Income Study (Fleming 1997, Fleming and Easting 1994, Taiapa 1994, Pasikale and George 1995). But writing two versions absorbs twice the amount of time and energy, if not more. 
Adopting a different strategy, I have chosen to write only one book on each particular topic, targeting intelligent adults with an interest in the social sciences and cross cultural communication. But this too always takes more time than expected. Revising my doctoral thesis to these ends took me five years and two re-writes and still attracted complaints of 'stodge' from one reviewer. I like to think I have improved my writing skills over the years but there are always some readers who find a text heavy going and others who interpret its readability as lack of depth.

The second problem is finding a publisher. Often the writer has to meet some or all the cost themselves. I have been fortunate in being accepted by academic publishers: my first book was published by Athlone (London University) Press with the help of a Maori Purposes Fund grant; two were published by Routledge and Kegan Paul; three by Victoria University Press; and one each by Learning Media and Auckland University Press. While academic presses carry a valuable imprimatur, they typically publish small print runs and have small publicity budgets, restricting sales to those already interested. However, if a work meets a recognised need it can sell steadily by word of mouth. Talking Past Each Other (Metge and Kinloch 1978) has been reprinted nine times and is still in print. Bookshops and libraries tend to shelve books from academic presses in academic rather than general sections and keep them in central locations rather than the suburbs.

Thirdly, with books (as indeed with most forms of communication) there is always the danger of being misinterpreted by readers with their own agenda. In the 1970 s a friend in South Africa wrote telling me that my account of urban Maori ranging the seashore and countryside accessible from Auckland at weekends and after work to gather shellfish, fish, puha (sowthistle) and watercress was interpreted there as evidence of the poverty stricken and backward state of the Maori population. This conveniently ignored my explanation that they did so to satisfy a craving for foods valued for their own sake and as a distinctive feature of Maori culture (Metge 1964:225).

Books written with non-anthropological audiences in mind are often overlooked by mainstream anthropologists - distrust of applied anthropology lingers in the heartland. Few of my books have been reviewed as anthropological works and they have been right off the radar when it comes to overviews of New Zealand anthropology. Ironically, other university departments, especially education, psychology and social work, prescribe them because of the light the anthropological perspective sheds on their disciplines. Others have had similar experiences. Julie Park's works are admired and used in the health 
field, Judith Simon's in education, Jeff Sissons' in political studies. Perhaps it is simply a matter of surviving long enough to become history. Last year Routledge issued a facsimile edition of The Maoris of New Zealand: Rautahi (Metge 1976) in its series Routledge Library Editions in Anthropology and Ethnology for the South Pacific and Australasia, ${ }^{12}$ and Berg did the same for $A$ New Maori Migration (Metge 1964). The Waitangi Tribunal used the latter in the Muriwhenua Land Report as an historical source (Waitangi Tribunal 1997: 373-76). I find this as amusing as it is gratifying, in view of criticism of my work as ahistorical (Webster 1998: 140-42) ${ }^{13}$ and because the explanation for what I was doing which Maori found most acceptable was the contention that 'I am writing history as it happens'.

\section{ETHNOGRAPHY AND THEORY}

In his cartoon Urry depicts Ethnographyville as separated from and barely aware of the existence of Anthropologyland over the hills; in his article in this issue he chides Anglo-American anthropologists for being so obsessed with ethnography that they neglect more general anthropological explanations and generalisations. I agree with Urry that too few anthropologists move from writing ethnography to wide ranging comparison and high level theorising. However, in mitigation I would point out that not all anthropologists are attracted to or equipped for such activities. While he acknowledges that ethnography, ethnology and anthropology constitute 'a continuum that is not easily segmented', Urry's formulation tends to support rather than dispute the view that ethnography is primarily descriptive, inductive and theoretically limited.

The tendency of some to refer to particular works as 'only ethnography' and particular practitioners as 'only ethnographers' raises my hackles in the same way as hearing a woman put down - or worse putting herself down - as 'only a housewife'. I reject the idea that ethnography is necessarily limited as regards theory. As I understand it and was taught by my anthropological mentors ${ }^{14}$, good ethnography is firmly grounded in and inspired by an understanding of Anthropology as the comparative study of all human societies and cultures. Fieldworkers draw on the theoretical paradigms available to them through their training and reading, in choosing their research arena, in deciding what to observe and what connections to make, in analysing, ordering and explaining their observations, and in presenting their findings. While they use induction to draw generalisations out of the mass of particular observations, they alternate it dialectically with deduction from existing theories to build explanations for particular situations. These procedures are not postponed until fieldwork is complete, but are embedded in the fieldwork process from 
the beginning. In making sense of their observations and solving the problems presented they refer constantly to their experience in their own society and to what they have read about other societies; comparison is one of the fieldworker's most useful tools and a distinctive feature of the way anthropologists work at all levels. Both in and outside academia, anthropologists are valued as team members by practitioners of other disciplines because of the insights they have to contribute, in particular, for their access to theoretical formulations about all human societies and cultures, their comparative perspective and their awareness that there are other ways of doing most human activities.

One of the reasons why some of our colleagues have difficulty discerning the theory in particular ethnographies is because those of us who write for audiences in the wider society avoid highlighting our theory in order not to alienate or (worse) bore those we wish to reach; instead, we find ways to express it in simple, non-technical language, even perhaps embedding it below the surface of the text, like the structural framework of a building.

Another reason is that anthropologists who tackle practical problems in the wider society typically take an eclectic approach to theory, rather than working within a single, encompassing paradigm. Because our primary focus is on understanding the particular situation under study, we prefer to start with a few basic guiding principles (such as the expectation that people's behaviour will make sense, even when at first it seems irrational) and weave in insights from varied sources as they prove helpful in handling the problems encountered. We expect the theories we develop to feed back into the discipline at a higher level to inform and challenge other work. Unfortunately, colleagues committed to one global paradigm have difficulty discerning the theory in our work and/or sometimes make the wrong identification. Many years ago a reviewer delving below the surface of my book, In and Out of Touch: Whakamaa in Cross Cultural Context, triumphantly identified the underpinning theory as Culture and Personality. ${ }^{15}$ I was at once offended and wryly amused; of the many paradigms I have encountered over the years Culture and Personality attracted me so little that I did not pursue it past an elementary level. ${ }^{16}$

\section{CONCLUDING COMMENTS}

I do not see ethnography as a palisaded village cut off from the general field of anthropology. On the contrary, I regard it, with comparison, as one of anthropology's most distinguishing and distinctive features. It is vitally important as the foundation on which we build, the source on which we draw for information and inspiration when fulfilling our responsibilities to the wider society no less than to 
our anthropological colleagues. But to fulfil these functions, ethnography must be grounded in understanding of, and constant dialogue with, general anthropological insights into the human condition.

New Zealand is a small country and the Anthropology departments in its tertiary institutions are necessarily limited in size. Most of their graduates find employment in the wider society because of interest in the problems and issues to be studied there as well the scarcity of university positions. Because practising anthropologists are scattered throughout the country in so many different locations, inside and outside academia, it is not easy for us to keep in touch with each other and the work we are doing. Since its inception in 1975, the ASAANZ has included anthropologists from both within and outside academia in its membership, brought them together in annual conferences, and experimented with various ways of keeping them in touch. We have to face up to the fact, however, that only a small percentage of anthropology graduates become members of ASAANZ, while members employed outside academia rarely belong for more than two or three years before allowing their membership to lapse. In writing the paper on which this article is based I realised how little I knew of the work other members of ASAANZ had done: even when I had a general knowledge of the work of close associates I had to request CVs to provide the necessary details for the four profiles above. I was also reminded how quickly such knowledge is lost to current practitioners, particularly with regard to the pioneers of community outreach, like John Booth and Ralph Piddington.

I am particularly concerned about the position of those anthropologists who work in the wider society on their own and in multi-disciplinary teams. Anthropologists are recruited and valued for their anthropological skills, in particular their expertise as fieldworkers, their comparative perspective and their theoretical knowledge, yet to develop and keep these skills honed they need at least periodic interaction with other anthropologists.

In the face of our dispersal and a working climate which often emphasises individual achievement over collegiality, we need, I believe, to become pro-active in recognising and supporting each other. We need to know much more than we now do about the work we are engaged in, the theoretical stances we adopt, and the challenges we face. We need to make it much easier to identify and locate those we want to talk to, criticise and debate with and those whose interests march with ours. The Association of Anthropologists of the Commonwealth produces and periodically updates a List of Members with details of training, employment, areas of interest and major publications; however, deceased members are omitted and coverage has reduced with increases in membership and costs. 
Technological advances should make a similar initiative in New Zealand easier and cheaper to compile. Could the ASAANZ's embryonic website be developed to store information about all the anthropologists working in New Zealand, in order to facilitate communication and debate? What could Anthropology Departments at tertiary institutions do to draw in and support anthropologists working in the wider society? What can we do individually and collectively to encourage mentoring relationships between older and younger anthropologists, inside and outside academia?

Perhaps what is most needed is a personal commitment to value and encourage our anthropological colleagues more, making the effort to contact each other directly, to talk face to face and to refer back anything we write about each other for checking. There are too few of us to misjudge and undermine each other in public. If we worked harder at keeping in touch and learning from each other, perhaps more of us might be inspired to venture out of Ethnographyville to explore the road through the hills to Urry's Anthropologyland.

\section{ACKNOWLEDGMENTS}

My sincere thanks to Jeff Sissons, Ann Chowning, Robin Fleming, Bernie Kernot and Julie Park for reading and commenting on the draft of this paper.

\section{NOTES}

1 In its Principles of Professional Responsibility and Ethical Conduct the ASAANZ places 'Responsibility to the Wider Society' in second place, immediately after 'Responsibility to Research Participants' (ASAANZ 1992:3). Under this heading it summarises anthropologists' responsibilities as follows:

'Anthropologists are also responsible to the public - all presumed customers of their professional efforts. To them they owe a commitment to candour and to truth in the dissemination of their research results and in the statement of their opinions as students of humanity.

a. Anthropologists should not communicate their findings secretly to some and withhold them from others.

b. Anthropologists should not knowingly falsify or colour their findings.

c. In providing professional opinions, anthropologists are responsible not only for their content but also for integrity in explaining both these opinions and their bases.

d. As people who devote their professional lives to understanding humanity, anthropologists bear a positive responsibility to speak out publicly, both individually and collectively, on what they know and what they believe as a result 
of their professional expertise gained in the study of human beings. That is, they bear a professional responsibility to contribute to an 'adequate definition of reality' upon which public opinion and public policy may be based. However, anthropologists should not present themselves as spokespersons for people who have not given them their consent to act in such a capacity, and they should advocate the right of research participants to be heard directly in contexts where their lives may be affected.

e. In public discourse, anthropologists should be honest about their qualifications and cognisant of the limitations of anthropological expertise.

2 Schwimmer also had important articles published in the Journal of the Polynesian Society in 1963 and 1965 but these were not as easily accessible to the general public as the books were.

3 As Tutor Organisers for the Department of University Extension at the University of Auckland, Koro Dewes (Ngati Porou) and I organised what were possibly the first marae visits by groups including Pakeha when we combined classes to visit a poukai (gathering affirming loyalty to the Maori King Movement) at Te Awamarahi Marae, Tuakau, on 24th November 1962 and Turangawaewae Marae, Ngaruawahia, on 1oth October 1964. With respect to in-service training for public servants, I worked with George Parekowhai (Rongowhakaata), John Tapiata (Te Arawa), Tamati Reedy and Wiremu Kaa (Ngati Porou) in the Colleges and Department of Education and with Derek Asher (Tuwharetoa) in the Department of Social Welfare in the 1980s, and with Haami Piripi (Te Rarawa) and Tukaki Waititi (Ngapuhi) in the Department of Corrections in the mid 1990s.

4 I have in my possession letters exchanged with J.K.Hunn in connection with his Report on the Department of Maori Affairs 24 August 1960.

5 As Fifth Captain James Cook Research Fellow 1981-83.

6 For example, Margaret Orbell (Maori literary studies) and Michael King (Maori biography and history).

7 I am especially grateful for the aroha shown by Fred Ellis (Te Rarawa) and Pita Sharples (Ngati Kahungunu) and the whanau at Hoani Waititi Marae.

8 For example, Bernie Kernot and Jeff Sissons.

9 This was clearly evident at the conference of the New Zealand Historical Association at Auckland in November 2005. Twenty of the 97 papers were on subjects 
relating to Maori, presented by both Maori and Pakeha historians.

10 See note 3 above. Since 2000 I have worked with Pare Nathan (Waikato) in workshops for Kaitaia College staff; with Tavake Afeaki (Ngati Porou and Tongan) at a conference of mediators in Sydney; and with Hone Sarich (Ngapuhi) in Brisbane.

11 I chose these four anthropologists on the basis of lengthy acquaintance with their work but requested CVs to ensure accurate reporting. All have approved these summaries of their work.

12 Routledge amended the title to Rautahi: The Maori of New Zealand on the cover and additional title page of the facsimile edition.

13 Webster makes a valid point. Trained under Piddington, a Malinowskian functionalist, I chose for many years to concentrate on reporting the contemporary situation as encountered in fieldwork, a task which kept me fully occupied, and left it to colleagues to explore the historical dimension. However, I have always been interested in change over time. In early works I used individual life histories and recollections to cast light on the changes of previous twenty years or so; in the 1990s I experimented with applying insights gained in the present to the study of the interaction between Maori and Pakeha in the 1830 .

14 Notably, Professor Ralph Piddington of the University of Auckland and Professor Raymond Firth of the London School of Economics and Political Science.

15 In the circumstances I prefer not to reveal the reviewer's identity.

16 I can best illustrate this point with reference to the diverse sources of my own theory. Introduced to anthropological theory through Piddington's exposition of Malinowskian functionalsim I adopted those parts of that paradigm which made sense to me (for example, the interconnectness of all aspects of a society, the concepts of status, role and function) but rejected others (the reification of the organic analogy, the theory of needs and the concept of equilibrium). At the London School of Economics I took on board some of Radcliffe Brown's principles of social structure (such as the equivalence of alternate generations) and added Firth's formulations of concepts of social organisation, optation and reciprocity. Under Jan Pouwer at Victoria University of Wellington I was catapulted into close encounter with linguistics, semiology, French and Dutch structuralism and Marxism. Drawing on these sources, I developed my own take on theories of signification, the mediation of opposites, transformation, bricolage and dialectic processes, while continuing to value the people's own insights into their culture. 


\section{REFERENCES}

Abel, S. et al. 1999. Infant Care Practices, Auckland: Department of Maori and Pacific Health, University of Auckland.

Anae, M. et al. 200o. The Roles and Responsibilities of Some Samoan Men in Reproduction, Auckland: Pacific Health Research Centre, University of Auckland.

Association of Social Anthropologists of Aotearoa New Zealand, 1992. Principles of Professional Responsibility and Ethical Conduct, as adopted in 1987 and amended in 1990 and 1992.

Booth, J. 1959. 'A Modern Maori Community', in J.D.Freeman and W.R.Geddes (eds) Anthropology in the South Seas, New Plymouth: Thomas Avery \& Sons Limited: $235-245$.

Dew, K. and R. Fitzgerald (eds) 2004. Challenging Science: Science and Society Issues in New Zealand, Palmerston North: Dunmore Press.

Hunn, J. K. 1961. Report on Department of Maori Affairs 24 August 1960, Wellington: Government Printer: 83 Appendix A.

Hunn, J. K. and Booth, J. 1962. Integration of Maori and Pakeha, Wellington: Government Printer.

Fleming, R. 1997. The Common Purse: Income Sharing in New Zealand Families, Auckland: Auckland University Press with Bridget Williams Books.

Fleming, R. and Easting, S. K. 1994. Couples, Households and Money: Report of the Pakeha Component of the Intra Family Income Study, Wellington: Intra Family Income Study.

Hohepa, P. W. 1964. A Maori Community in Northland, Auckland: The Anthropology Department, Auckland University.

Kernot, C.B.J. 1972. People of the Four Winds, Wellington: Hicks Smith.

Metge, J. 1964. A New Maori Migration: Urban and Rural Relations in Northern New Zealand, London: Athlone Press. 
Metge, J. 1976. The Maoris of New Zealand: Rautahi, London: Routledge \& Kegan Paul.

Metge, J. 1986. In and Out of Touch: Whakamaa in Cross Cultural Context, Wellington: Victoria University Press.

Metge, J. 1991. Evidence of Alice Joan Metge in Respect of Wharo Te Oneroa a Tohe, Report to the Waitangi Tribunal, 50 pages.

Metge, J. 1992. Cross Cultural Communication and Land Transfer in Muriwhenua 1832-1840, Research Report to the Waitangi Tribunal, 161 pages.

Metge, J. 1993. Comments on "Issues Arising From Pre-Treaty Land Transactions" by Fergus Sinclair, Report to the Waitangi Tribunal, 32 pages.

Metge, J. 2000. 'Piddington, Ralph O'Reilly 1906-1974', in The Dictionary of New Zealand Biography: Volume Five, Wellington: Department of Internal Affairs: 411-12.

Metge, J. 2004. Ropeworks: He Taura Whiri, Waitangi Rua Rau Tau Lecture 2004, www.radionz.co.nz.

Metge, J. and Kinloch, P. 1978. Talking Past Each Other: Problems of Cross-Cultural Communication, Wellington: Victoria University Press.

Park, J. 1982. Doing Well: an Ethnography of Coping, Auckland: Anthropology Department Working Paper 61.

Park, J. 1985. Social Relationships in a Psychiatric Hospital, Wellington: Department of Health.

Park, J. (ed.) 1991. Ladies a Plate: Change and Continuity in the Lives of New Zealand Women, Auckland: Auckland University Press.

Park, J., Scott, K. et al. 1995. A Bleeding Niusance: Living with Haemophilia in Aotearoa/New Zealand, Auckland: Department of Anthropology, University of Auckland.

Piddington, R. and Graham, J. 1940. Anthropology and the Future of Missions, Aberdeen: The University of Aberdeen Press. 
Piddington, R. 1951. 'An Anthropologist's Viewpoint', Chapter Two in The Yearbook of Education 1951 (UK). Reprint published in association with the University of London Institute of Education.

Piddington, R. 1951. 'Synchronic and Diachronic Dimensions in the Study of Polynesian Cultures', Journal of the Polynesian Society Vol. 6o (2 \& 3):108-21.

Piddington, R. 1960. 'Action Anthropology', Journal of the Polynesian Society Vol. 69(3): 199-214.

Piddington, R. 1968. 'Emergent Development and 'Integration', in Eric Schwimmer (ed.) The Maori People in the Nineteen Sixties, Auckland: Blackwood and Janet Paul: 257-69.

Rata, E. 2004. 'Strands must be knit into a national whole', New Zealand Herald 9 January;

__ 'Forget ethnicities, focus on cultures', New Zealand Herald 11 February.

Schwimmer, E. 1966. The World of the Maori, Wellington: A.H. and A.W.Reed.

Schwimmer, E. (ed.) 1968. The Maori People in the Nineteen Sixties, Auckland: Blackwood and Janet Paul.

Scott, K., Park, J. et al. 1997. A Sense of Community, Auckland: Department of Geography, Occasional Paper 33, University of Auckland.

Tremewan, C. 2005. 'Ideological Conformity: A Fundamental Challenge to the Social Sciences in New Zealand', in Sites: a Journal of Social Anthropology and Cultural Studies, (N.S.) Vol 2 (1):1-44.

Waitangi Tribunal, 1997. Muriwhenua Land Report, Wellington: GP Publications.

Walker, R. 1987. Nga Tau Tohetohe: Years of Anger, Auckland: Penguin Books.

Webster, S. 1998. Patrons of Maori Culture: Power, theory and ideology in the Maori Renaissance, Dunedin: University of Otago Press. 